\title{
Innovative Research of Librarian Service Model in University Based on the Needs of Readers
}

\author{
Maoli Xu \\ library, \\ JiLin Agricultural University , \\ Changchun, China \\ Email: xmljlau@yeah.net
}

Keywords: university library; readers'needs ; librarian; service model

\begin{abstract}
Readers'demand is the driving force of library development, the ultimate goal of library services is to provide timely and accurate information services. Ideal subject service should be based on the needs of readers, go deeply into teaching, research and learning of users, provide professional and individualized value-added information services anytime and anywhere. We treat readers' needs as core guide, explore university library how to conduct service innovation of librarian on the basis of readers' needs.
\end{abstract}

\section{Introduction}

Users' demand is the driving force of library development, the ultimate goal is to provide timely and accurate information services. With the development of modern information technology, readers' requirements for library information services are also rising. Users don't require only a simple document retrieval and delivery any more, but expect that libraries can provide personalized, professional and strong time-sensitive information, provide a powerful counterpart services for teaching and scientific research in universities' users. Ideal subject service should be based on the needs of readers, go deeply into teaching, research and learning of users, provide professional and individualized value-added information services anytime and anywhere. How to innovate and deepen traditional disciplines services, how to change library management model from library-oriented to user-oriented, how to make information service disciplines and knowledge, which is an urgent requirement for subject service development in current universities library.

\section{Concepts and services content of librarians}

\section{A. The concept of librarian}

Librarian, also known as the subjectexperts, connect librarian, subject specialist librarians. They are comprehensive professional talents who own some academic background, receive professional training, provide in-depth, individual information access and use service for specific subject users. "University Librarian”, refers to the established professional of university library for some a college or disciplines major as counterpart department, set up a communicative bridge between college or discipline and library, timely exchange information and feedback, initiative, targeted screen and collect information for reader, meet the needs of subject information, provide some discipline services such as available resource, literature consulting solutions,information using training. To make full use of library materials, improve the utilization of literature ${ }^{[1]}$.

\section{B. Service content of librarian}

----Scientific Research Service. Building scientificresearch teams, learning disciplinary theory 
together, preparing for scientific service program. We should make a deep research for latest research subject situation at home and abroad, and form analysis report. For example, we classify and collect approving situation of the NSSF according to subjects, sent to the relevant institute for teachers' research as a reference; we provide track service and location service for teachers who have approved subjects, dig deeply knowledge in hot spot field, encourage teachers to declare topics, even join the research team and conduct scientific research; we have a information share with teachers such as thesis writing, knowledge retrieval; we apply kinds of topics actively, organize to learn academic dynamics about domestic and international tourism research ${ }^{[2]}$.

----Teaching Service. We analyze deeply teachers' curriculum, have a comparative analysis for teachers' textbooks, share with teachers about related class materials, PPT production knowledge and case studied. We establish professional and special courses resources, show students the national quality courses, provincial quality courses and other special courses in informativeway. Meanwhile, the library carry out course teaching of information literacy for teachers and students, so that more readers can learn theory and practical knowledge of information retrieval.

----Professional Services. We organize regularly team, classify and collect professional information using digital resources of library, and have a unified release. We have a unification and integration for the need informationof professionalsand situations of school talents, establish information communicative mechanism.

\section{The current status of discipline services}

\section{A. Services are not deep enough}

Current subject service is information service way which based on librarian, center on resource construction, one-way interaction, which also limited to provide passive information services such as routine reference consulting, subject GPS, subject databases and subject multimedia resources according to physical library resources ${ }^{[3]}$. Subject service has poor interactive, insufficient knowledge services, can’t provide knowledge support effectively and comprehensively for research work.

\section{B. The lack concern about the users and service effect}

Although many domestic universities libraries are carrying out the discipline service construction, only a few major libraries can provide subject service truly and effectively. Most libraries are still in the trial service stage of constructive disciplines database, readers' quality education and regular discipline navigation services, don't have enough attention and research for deep needs of user and subject service effects. Which always leads to inconsistent between subject service construction and user' needs direction, or can't play its role effectively.

\section{Professional degree of subject resources construction are low}

In the process of construction, some university libraries don't dig deeply the existing value of discipline data resource, only have simple organizational construction for existing subject resource, meanwhile we are lack of exploitation and use for network resources, don't have a enough depth for discipline resource construction, also limit to service effect.

\section{Supporting resource of discipline services are shortage}

Subject resources and subject librarian are basis for carrying out discipline service, Disciplinary service platform is an important means to carry out disciplinary services. Currently, the staff of domestic university library need to improve their subject professional quality and information technology level, subject librarian teams are shortage severely, the constructions of disciplines resources and service software are shortage, development and promotion of disciplines are hampered by many reasons ${ }^{[4]}$. 


\section{Service Model Innovation of Subject Librarian}

A. Overall service

For library, the biggest change today is the change from users'information environment, users can obtain information from the large-scale public source, digitized library collections and other network resources. The user look the search engine as the preferred choice to access information. Service model of librarian is established on the basis of network environment and digital resources, closely combine librarians with user information environment, in the traditional means of communicative services, we make diversity and integrity as a representative such as push service actively, personalized services, digital network consulting, enhance and expand the modern library function.

\section{B. Personalized service}

Personalized digital information service, is user-oriented and user-centered informative service, recommends personalized information services content for users' research in the network environment, meet the information needs that users solve problem. According to research progress and informative needs of university, librarian can create digital library organization as an administrator, establish informative environment that fit for every subject and every teachers, instruct teachers to establish personal digital library, use its powerful function to predict teachers' information needs, can carry out push service of disciplinary resources specially, combine closely service content with whole academic exchange process of teachers, including teaching references, project establishment, on the search of science and technology, papers published, the evaluation of results, literature search, realize networked and personalized tracking service.

\section{Active Service}

Simple technology and digital resources can't provide services for user, without the experience participate of librarians, the conflicts that complex and enormous digital resources, required information to access profession for users will highlight. Librarians can solve the problem because they have professional discipline background and skilled information-handling. Librarian should service actively, go into users' base deeply, understand subject construction and development situation, predict later invisible requirements from previous obvious requirements of users, save time and energy to search information for users. Meanwhile, we need to improve the quality of librarians, only provide harmony service, can we promote deep-level development of university library business.

\section{Discipline Consulting Services}

Under the network information background, librarian need to carry out multi-channel, personalized discipline consulting services, integrate into the user's virtual space, such as BBS, RSS, MSN, Blog, Wiki, QQ, etc., it is convenient to use distributed joint virtual reference system. By using these interactive technology, we allow everyone to become an information provider, organize information in dynamic way, make them in order ${ }^{[5]}$. We can establish blog system that librarian is blogger, release hot and leading issues of this discipline, users can click directly and go into it anytime. We use network digital technology to construct discipline service platform, users don't get customized individual services any longer, but participants and publisher of information, exchange their tacit knowledge into explicit knowledge, users can also inspire each other and realize expansion and innovation from knowledge.

\section{E. Collaborative Services}

When the collective resource scales can't meet the needs of users, when professional disciplines information of users have deeper needs, we can't solve the problem relying solely on library resources or single librarian. Librarians make use of the Internet platform to strengthen coordination and interaction with the users, optimize all types of library resources, strengthen internal collaboration among librarians, improve and answer difficulty, depth and accuracy from 
users advisory, make a collaborative job for document delivery and inter-library loan.

\section{Conclusion}

In the information ages with updated and accelerating knowledge, the demands from teachers and students in universities show gradually a specialized and diversified trends, which brings much challenges for librarian service. The different needs in different disciplines, which requires librarian have different ways to deal with work ideas and services. Only in this way, can we provide a better service for teaching, research and many teachers and students.

\section{Acknowledgements}

This paper is the research finding of the 12th Five Year Plan of education science in Jilin Province "The construction and practice of support platform of universities' library rescourse and service facing to the construction of key disciplines" in the year of 2015 (Item Number: GH150212) and the research project of National Agricultural Literature Information Center of CALIS "The deep integration and further research of the library resources under the background of Big Data” in the year of 2015 (Item Number: 2015019)

\section{References}

[1] Liu Min. Research of Subject Librarian Services, [J]. Sci-Tech Information Development \& Economy, 2011, 21(14): 74-76.

[2] Liu Ping. Reflections on "bottleneck" breakthrough of Subject Librarian System, [J]. Library Work in Colleges and Universities, 2009, 29 (3): 54-56.

[3] Hong Minglu. Comparative Analysis of University Library Service mode under traditional mode and network environment, [J]. Science and Technology Innovation Herald, 2009,22:215.

[4] Xiong Wenhui. On Information sharing space construction under subject service mode. [J]. Inner Mongolia Science \& Technology and Economy, 20133,(5):148-149.[10]

[5] Gao Xie, Song Haiyan, etc. On Planning and practice of Information Literacy Education which is innovation oriented-taking Shanghai Jiaotong University Library as an Example, [J]. Library and Information Service, 2013,(1):10-14. 